
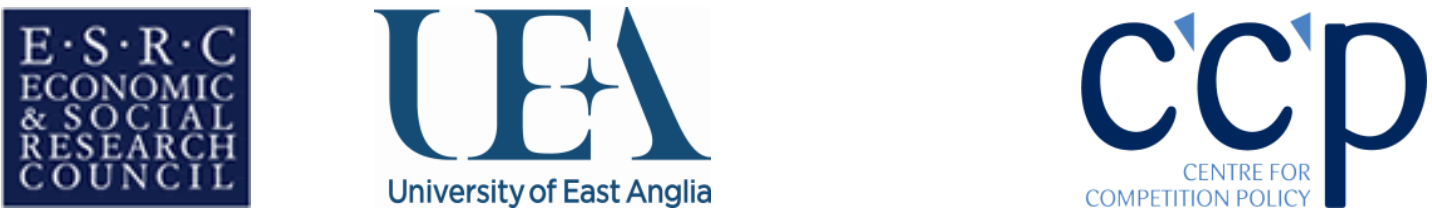

\title{
Non-discrimination clauses in the retail energy sector
}

\author{
Morten Hviid* \\ and \\ Catherine Waddams Price** \\ *UEA Law School and ESRC Centre for Competition Policy \\ ${ }^{* \star}$ Norwich Business School and ESRC Centre for Competition \\ Policy
}

\section{CCP Working Paper 10-18}

\begin{abstract}
The British Energy regulator will soon review a non-discrimination licence condition which it imposed to ensure that energy retailers charge the same mark-up in different regions. Many consumers are loyal to incumbent firms, necessitating heavy discounting by entrants to attract customers, which had led to regional price discrimination. Matching characteristics of the energy market to models of discrimination, we identify the necessary conditions for the licence condition to have a positive effect for consumers, and explore whether the policy has helped potentially 'vulnerable' consumers. We conclude that the most likely effect of the licence condition is to reduce competition in the mainstream energy markets, and welcome the regulator's latest review of the retail market.
\end{abstract}

November 2010

JEL Classification: L11, L13, L41

Keywords: Non-discrimination clauses, retail energy markets.

Acknowledgements: We gratefully acknowledge the financial support of the UK Economic and Social Research Council (ESRC). We thank participants in a UEA Energy Seminar, the University of California Energy Institute 2009 
summer camp, the Regulatory Competition and Regulation Conference at Oxford, The NMa in the Hague, the CIE conference at Copenhagen, the World Forum on Energy IV, the Electricity Policy Research Group Winter Research Seminar at Cambridge, the Centre for Consumers and Essential Services conference at the University of Leicester, The Ankara Bar Association conference, The Spanish Energy Economists Association, The Economic and Social Research Institute in Dublin, the CCP and RPI joint conference on "The Role of Competition in Public Policy" and the 2010 RES conference, as well as Zhijun Chen and other colleagues at CCP for many helpful comments and discussions, Hieu Tran and Oindrila De for excellent research assistance, and the Office of Gas and Electricity Markets for constructive debate and helpful information, The usual disclaimer applies.

\section{Contact Details:}

Morten Hviid, UEA Law School and ESRC Centre for Competition Policy, University of East Anglia, Norwich NR4 7TJ, UK; m.hviid@uea.ac.uk

Catherine Waddams, Norwich Business School and ESRC Centre for Competition Policy, University of East Anglia, Norwich, NR4 7TJ; c.waddams@uea.ac.uk 


\title{
Non-discrimination clauses in the retail energy sector*
}

\author{
Morten Hviid ${ }^{\dagger}$ \\ University of East Anglia \\ and \\ Catherine Waddams Price $^{\ddagger}$ \\ University of East Anglia
}

November 2010

\begin{abstract}
The British energy regulator will soon review a non-discrimination license condition which it imposed to ensure that energy retailers charge the same mark-up in different regions. Many consumers are loyal to incumbent firms, necessitating heavy discounting by entrants to attract customers, which had led to regional price discrimination. Matching characteristics of the energy market to models of discrimination, we identify the necessary conditions for the licence condition to have a positive effect for consumers, and explore whether the policy has helped potentially 'vulnerable' consumers. We conclude that the most likely effect of the licence condition is to reduce competition in the mainstream energy markets, and welcome the regulator's latest review of the retail market.
\end{abstract}

Keywords: Non-discrimination clauses, retail energy markets. JEL Classification Code: L11; L13; L41

${ }^{*}$ We gratefully acknowledge the financial support of the UK Economic and Social Research Council (ESRC). We thank participants in a UEA Energy Seminar, the University of California Energy Institute 2009 summer camp, the Regulatory Competition and Regulation Conference at Oxford, The NMa in the Hague, the CIE conference at Copenhagen, the World Forum on Energy IV, the Electricity Policy Research Group Winter Research Seminar at Cambridge, the Centre for Consumers and Essential Services conference at the University of Leicester, The Ankara Bar Association conference, The Spanish Energy Economists Association, The Economic and Social Research Institute in Dublin, the CCP and RPI joint conference on "The Role of Competition in Public Policy" and the 2010 RES conference, as well as Zhijun Chen and other colleagues as CCP for many helpful comments and discussions, Hieu Tran and Oindrila De for excellent research assistance, and the Office of Gas and Electricity Markets for constructive debate and helpful information. The usual disclaimer applies.

†UEA Law School and ESRC Centre for Competition Policy, University of East Anglia, Norwich NR4 7TJ UK; e-mail: m.hviid@uea.ac.uk.

$\ddagger$ Norwich Business School and ESRC Centre for Competition Policy, University of East Anglia, Norwich NR4 7TJ UK; e-mail: c.waddams@uea.ac.uk. 
"The remedy [a prohibition on undue price discrimination] would have malign and unintended consequences:

As it will bear unevenly on different market players with the effect of restricting and distorting competition ...

Fixed margins over all propositions would destroy the competitive market" (Response to Ofgem's energy Supply Probe by RWE, a major player in the market, 1st December 2008)

\section{Introduction}

In September 2009 the British energy regulator, Ofgem, imposed a non-discrimination requirement on energy retailers, preventing them from charging different mark-ups in different regions. ${ }^{1}$ Their aim was to address perceived disadvantages suffered by some consumers in the competitive market, and since the clauses were implemented for three years in the first instance, the regulator will soon be reviewing them. The key focus for the policy change, and for this paper, was the differences in a firm's price across the 14 original regional electricity markets. Prices also differed across other dimensions such as payment methods, and non-discrimination clauses to eliminate these differences were introduced at the same time, following European Community directives. ${ }^{2}$ While the two policies interact in ways which we discuss in the conclusion, our main attention here is on differences in price across regions. Regional markets remain well-defined not just for electricity but also for the bundled supply of electricity and gas. We explore the effect of the non-discrimination requirement on prices and profits and on the group of consumers that Ofgem is charged with protecting.

The issue identified by Ofgem arises from the process by which the competitive market developed. Prior to opening the markets to competition, each region was supplied by a single regional electricity incumbent and a single national gas incumbent. When the electricity and gas markets were opened, entrants, who were predominantly incumbent electricity suppliers from other regions plus the national gas incumbent, ${ }^{3}$ undercut

\footnotetext{
${ }^{1}$ A similar regulation was imposed on energy companies in Germany in 2006, see Gesetz gegen Wettbewerbs-beschränkungen (GWB) § 29.

${ }^{2}$ Directives 2003/54/EC and 2003/55/EC of June 2003 concerning common rules for the internal markets in electricity and gas.

${ }^{3}$ Of the firms who have survived in this sector for more than two years, the only one which was not a
} 
the established suppliers to attract consumers to switch. At the time of the regulator's investigations in 2008, a decade after competition was introduced, it remained true that in any one region the entrants generally offered prices lower than the incumbents in that region. Consumers who switched away from the incumbent could save around $10 \%$ of their bill, yet almost half stayed with their original supplier, indicating substantial "loyalty" amongst such consumers. ${ }^{4}$ Whether this loyalty arose from genuine affection for the incumbent or from inertia is not a matter for this paper, but its consequences are. ${ }^{5}$ From the retailers' perspective, each of whom was incumbent in some regions and entrant in others, the loyalty of home consumers enabled them each to charge around $10 \%$ more (relative to costs) to those at home than to those in regions where it was entrant. Ofgem's licence conditions aimed to remove such differentials.

In the existing economics literature, there are two strands which are relevant when assessing the new requirement. From the literature on price discrimination in oligopolistic markets, summarised by Stole (2007) and Armstrong (2008), a robust finding is that banning price discrimination will raise some and possibly all prices in the market. In the simplest scenario, where costs are assumed identical across firms and regional markets, the non-discrimination requirement reduces to a most-favoured-customer (MFC) guarantee. A second strand of literature illustrates that when such a guarantee is aimed at final consumers, it generally raises prices and lowers welfare. ${ }^{6}$

We use the salient features of the British energy markets (presented in section two of the paper) to assess the policy of Ofgem in the light of the existing literature. This liter-

regional incumbent elsewhere is Centrica who was the incumbent gas supplier in all the regions and who hence had some brand loyalty and recognition amongst the eighty percent of households who consumed gas. Since gas is cheaper for space heating than electricity, those households who do not use mains gas are generally in a geographic area with low population density which is not connected to the gas distribution grid.

${ }^{4}$ For an estimate of such loyalty based on consumer responses in the early days of liberalisation of the gas market, see Giulietti et al. (2005).

${ }^{5}$ Since the product for technical reasons must be homogeneous, the reliability of the supply depends on the monopoly distributer and not on the retailer and the services surrounding the supply vary little across firms, the possibility for a retailer to differentiate looks thin. However the reality of consumer perception may differ.

${ }^{6}$ The literature demonstrates that if the MFC is aimed at final goods consumers, then this will generally result in them paying higher prices, see e.g. Cooper (1986), Neilson and Winter (1992, 1993) and Hviid and Shaffer (2010). 
ature, which is summarised in section three, highlights the importance of how individual firms assess each of the submarkets in which they are active. In section three we also apply the insights from the literature to the energy market and identify some consequences of introducing the policy. Section four pinpoints the characteristics of those who have not switched away from the incumbent, whom the policy is designed to protect, to assess how far the policy meets the regulators' objectives. Recent responses to the prohibition and their implications for competition and protecting vulnerable consumers are also explored. Section five concludes and supporting evidence is presented in an appendix.

\section{Salient features of the British energy markets}

The vertical structure of the British gas and electricity industries had been established by 1996, when retail energy markets were first opened. Of the four vertical stages (generation/gas supply, transmission, distribution and retail) we are concerned with the final, retail, stage. Prior to market opening, each of the fourteen regions in England, Wales and Scotland was supplied by a regional electricity incumbent which also owned the distribution wires. Households which were connected to the gas network bought gas from a national gas incumbent. The gas market opened between 1996 and 1998, and each regional electricity market over an eight month period between 1998 and 1999. The electricity distribution function was separated from retail, and each region's distribution continued to be undertaken by a regional monopoly. ${ }^{7}$ These monopolies levied a published regulated tariff which was offered on a non-discriminatory basis to all retailers, including each firm's own retail arm, though the distribution costs and prices (both levels and structures) differed between regions because of regional supply and demand characteristics and historical custom. Virtually all the incumbents (national gas and regional electricity) entered all the other markets, along with other entrants. By 2008, takeover and exit had reduced the number of players in each regional electricity market to a (consolidated) descendant of the original incumbent, the national gas incumbent, and four companies whose predecessors

\footnotetext{
${ }^{7}$ In subsequent years ownership of the distribution wires and the incumbent retailer became separated in seven of the fourteen regions.
} 
had been incumbent in other regions. ${ }^{8}$ The same players met in the national gas market.

Price caps had been applied to the incumbents since their privatisation, and these continued after the markets were opened until 2002, when the regulator judged that competition was sufficiently developed for all restrictions on retail prices to be removed. The energy market continued to be subject to existing competition law. Of particular relevance is the prohibition of undue discrimination by firms which were judged to be dominant in a particular market (regional or national) found in Chapter II of the UK Competition Act 1998. By imposing a non-discrimination requirement on the energy retailers, Ofgem avoided any uncertainty about the applicability of competition law arising either from the issue of whether the law relates to consumers as well as customers or whether the firms in question were dominant.

All consumers stayed with the incumbent(s) unless they made a positive move to switch. Such activity was encouraged by marketing and doorstep and telephone sales promotions. Many campaigns were focused on persuading consumers to purchase both gas and electricity from a single supplier under a dual fuel deal, which offered a discount on the combined price of buying each fuel separately. By late 2008 the regulator reported that $75 \%$ of households had switched their supplier for gas or electricity at least once (Ofgem, 2008). In December 2007, around two thirds of consumers with access to both gas and electricity supply bought both fuels from the same supplier, and ninety percent of switching in the year to October 2008 had been to a single supplier for gas and electricity. Ofgem reported that approximately half the consumers who switched their gas supply from British Gas had moved to the electricity incumbent, and a similar proportion of those who had left the electricity incumbent changed to British Gas. As a result, despite the high number who had switched once, the two incumbents retained around $70 \%$ of the combined market. Of all the gas and electricity accounts (including dual fuel) for consumers where both gas and electricity were available, the gas incumbent supplied $38 \%$, the regional incumbents $36 \%$ and the combined share of the four other electricity

\footnotetext{
${ }^{8}$ Each electricity supplier is typically an incumbent in three regional markets and an entrant in a further eleven markets, while the former gas incumbent is an entrant in all fourteen regional electricity markets.
} 
firms was $25 \% .^{9}$ No other entrant had achieved a significant market share, and all such firms had left the industry. ${ }^{10}$

From the perspective of the firms, these market developments left each former electricity incumbent with $57 \%$ of their consumers 'in-area': $42 \%$ were electricity and $15 \%$ gas accounts; while the remaining $43 \%$ were out of area consumers, evenly divided between electricity and gas accounts (Ofgem 2008, p. 34). Electricity companies therefore supplied more consumers in markets where they were formerly incumbents than in areas where they were entrants (whether measured by electricity accounts alone or total energy accounts). Despite the homogeneity of the basic product, incumbents were able to maintain prices around $10 \%$ higher than those of entrants in each region, while retaining almost half of the market (Ofgem, 2008). Home markets were therefore also more profitable because incumbents were able to charge a higher mark-up in these areas.

British (Scottish) Gas was the national gas incumbent and had a strong customer base in each region, but it served a smaller number of consumers in some areas than others, and these represented a smaller proportion of the potential electricity accounts in areas where fewer households were connected to the gas distribution grid. ${ }^{11}$ In May 2008, immediately before suppliers started to respond to the growing call to eliminate regional price differences, the prices charged by British Gas to large residential dual fuel consumers, who were most likely to be the focus of competition, indicate that it generally positioned itself close to the incumbent electricity supplier; in seven regions the prices were virtually identical for dual fuel high volume customers, and in four of the remaining regions the two incumbents' charges were closer to each other, and higher than, those of the entrants. ${ }^{12,13}$ Nevertheless, the markups charged by British Gas in each region (calculated on the basis of the difference between published price and publicly available regional distribution tariffs for medium sized consumers) show only small differences in this

\footnotetext{
${ }^{9}$ Own calculations based on Ofgem (2008).

${ }^{10}$ Other firms have since entered the industry.

${ }^{11}$ See table $\mathrm{A} 1$ in the appendix.

${ }^{12}$ See table A2 in the appendix.

${ }^{13}$ Some of the differences in other regions arise from firms levying different tariff structures (see Davies et al., 2009), so that measuring charges to any one group reveals anomalies, but the pattern is consistent.
} 
crude measure of 'profitability' between regions in May 2008, with a standard deviation of less than $4 \%$ of the profitability. ${ }^{14}$ The year before the probe, the company claimed that "British Gas' standard dual fuel tariff is now cheaper than the local supplier in every area of the country, and Click Energy remains the cheapest energy tariff on the market" (Centrica, 2007), indicating a national marketing approach rather than a focus on particular regions. The national policy was reaffirmed in 2010: "British Gas [has been] on average the cheapest supplier of standard electricity across Britain....the company is now also the cheapest major supplier of standard gas at average consumption - and therefore of dual fuel - right across Britain" (Centrica, 2010). British Gas clearly sees itself as a major national player rather than taking different approaches to the individual regional markets.

To sum up, the key features of this market are as follows. The market consists of a number of well defined regional submarkets, each characterised by the presence of two incumbents and four entrants. Of the two incumbents, one is an incumbent in all submarkets, while the other is an incumbent in a small number of submarkets while being an entrant in all remaining submarkets. The entrants are all incumbents in some other markets. The market is characterised by the presence of strong brand loyalty for the incumbents. A substantial number of consumers, up to $70 \%$, act as if they have strong preferences for taking their energy supplies from a firm with incumbency status. Moreover because consumers require substantial price reductions by entrants to overcome this loyalty to incumbents, the surplus generated for each firm from out-of-area sales must be much smaller than from its in-area sales. Not only is the mark-up smaller, total sales are also lower, with the majority of each supplier's customers still in their incumbency regions. For the former electricity incumbents, the in-area markets are hence more important then the out-of-area markets. For the former gas incumbent all the publicly available direct evidence indicates that it takes a national approach to the market. Finally, price discrimination between regions was evidently being practised by the electricity firms who charge more in-area than out-of-area.

\footnotetext{
${ }^{14}$ See table A3 in the appendix, especially column four.
} 


\section{Relevant literature}

The existing literature on price discrimination has recently been surveyed in Stole (2007) and Armstrong (2008). Here we focus on the subset of the literature relevant to our specific oligopolistic setting. Corts (1998) classifies the possible results arising from duopoly models of price discrimination. In a fairly general set-up where there are two firms and two market segments, he provides some general insights into the effect of price discrimination on prices. The key to understanding the effects is to recognise that for each firm, there must be a "strong" and a "weak" market in the sense that if the rival sets a uniform price, the firm would set a higher price in the strong market. ${ }^{15}$ The crucial factor is whether the firms agree on which market is strong. If they do, the market is said to display best reply symmetry. If not, it is said to display best-reply asymmetry. The important insight in Corts (1998) about the effect of allowing discrimination is that "firms may price more aggressively in some markets when permitted to discriminate; if firms differ in which markets they target for this aggressive pricing and competitive reactions are strong, prices in all markets may fall.", (p. 321). To put it more simply, if forced to treat markets the same, firms will retrench to the markets where they make the most money. If firms retrench to the same market, they will start competing vigorously for it and thereby drive prices down. If they retreat to different markets, each will find itself facing less intense competitive restraint, will be able to behave more like a monopolist, and raise their price. Below we provide a short summary of the key models of best-reply symmetry and asymmetry. ${ }^{16}$

The case of best-reply symmetry, where firms agree on the ranking of submarkets, has been analysed in a number of previous papers, such as Borenstein (1985), Holmes (1989), Thisse and Vives (1988), ${ }^{17}$ Dobson and Waterson (2006), and Winter (1997). In

\footnotetext{
${ }^{15}$ Annex 6 (pp128-133) of Ofcom (2010) presents a good summary of this literature.

${ }^{16}$ Another class of papers, noticeably Fudenberg and Tirole (2000) and Bouckaert at al (2008), analyse discrimination in a dynamic context. These models consider a single market but assume that consumers become locked in from past purchasing behaviour. Although interesting in a general context, this class of models does not fit industries with several regional markets very well.

${ }^{17}$ Thisse and Vives (1988) find that banning discrimination in the case where firms can perfectly price discriminate makes firms better off.
} 
the duopoly version of these models, both firms would have the higher equilibrium price in the same market segment. If discrimination were banned, one would always find that the uniform price would be between the two prices chosen when discrimination is permitted, and hence the effect on consumers is ambiguous without additional structure placed on the model. This is the scenario which Ofgem hoped for: in-area prices would be lower, benefitting those consumers who have not yet switched.

In models which assume best response asymmetry, the theory predicts that many outcomes are possible. In particular, it is possible for all prices to increase or to fall when moving from price discrimination to uniform pricing. This is determined by the importance to the firm of its strong market. ${ }^{18}$ A strand of this literature considers two firms, each with their own "turf", perhaps arising from loyalty. The simplest case is described in Bester and Petrakis (1996) using an address model, where half the consumers are located at one end of the line with one of the firms and the other half at the other end of the line with the other firm. Consumers have a reservation price , $v$, and face a cost, $s$, from buying from the "outside" firm. If firms can discriminate and so set different prices to their in-area and out-of-area consumers, firms compete directly with each other and have to limit price to $s$ to remove the competitive pressure. Thus each price is equal to the "switching" costs and firms still sell only to their own in-area consumers. If there were a ban on discrimination, so long as $v$ is sufficiently greater than $s$, each firm would price at $v$. Thus a ban on discrimination trivially raises all prices. Bester and Petrakis generalize this model and while other models use a richer model set-up, the intuition above generally applies. ${ }^{19}$ Shaffer and Zhang (2000) consider a two firm - two market model and allow for asymmetry in the size of the relative markets as well as the degree of loyalty across the two markets. They show that banning price discrimination will always harm some consumer groups and they derive sufficient conditions for all consumers to be harmed by such a prohibition. In cases where some consumer groups benefit from a ban on discrimination, these are only consumers in the smaller market and most typically among the consumers

\footnotetext{
${ }^{18}$ For the energy market we have argued in the previous section that the in-area markets are not just the "strong" markets but also the most important in terms of revenue.

${ }^{19}$ Thus Chen (1997) also finds that a ban on price discrimination harms all consumers.
} 
loyal to the incumbent in this smaller market. ${ }^{20}$ Thus if best-reply asymmetry is the most appropriate assumption, then, at best, the set of consumers likely to benefit would be relatively small, and at worst ${ }^{21}$ all consumers would lose. The source of the most likely competitive constraint on the incumbents is therefore crucial in determining the effect of imposing non-discrimination.

While both literatures do identify cases where some consumers will gain from a ban on price discrimination, the identity of the group which will benefit differs. With best reply symmetry, there is a segment currently with the incumbent within each region which will gain. With best-reply asymmetry, if there are any consumers who gain they will be with the incumbent, but this can only occur in some of the regions.

\subsection{Application to the UK energy market}

In the UK energy market it is not immediately obvious whether the market displays best-reply symmetry (firms share the same belief about which submarkets are "best", i.e. strong) or asymmetry (firms have differing beliefs about which markets are "best"). We proceed by considering various plausible scenarios, first addressing the geographical dimension.

If the gas incumbent has no clear preference over the regions and hence provides the same competitive constraint in each one, we can take this firm out of the equation - it essentially shifts residual demand in the same way in each submarket. In this case, when we evaluate the effect of banning price discrimination, in each market there is one firm (the former monopolist) for whom this market is strong and each electricity firm will retrench to its preferred market. For this form of best-reply asymmetry, it is clear that all prices are expected to increase. The extent of the increase depends on the strength of

\footnotetext{
${ }^{20}$ Two other relevant papers are Shaffer and Zhang, 1995 and Shaffer and Zhang, 2002. More recent literature by Chen and Zhang, 2009, and Esteves, 2009, identifies some circumstances where banning price discrimination would benefit consumers. However, their result depends on some consumers being infinitely loyal to incumbents in the sense that they would never buy from anyone else, and are driven by a need to identify these consumers through initial pricing. Both papers employ a two period model in which, in the first period firms price very high in order to identify the loyal consumers to enable second-period price discrimination. This high "identification" price harms consumers.

${ }^{21}$ This is the more likely case as the strong markets are also the most important markets.
} 
competitive restraint the national incumbent places on its rivals. Where the competition between the two incumbents is very keen, the effect on prices may be relatively modest. However, it does not seem credible that this competition is highly intensive given the markups which the incumbent electricity firms were able to charge.

If instead of being indifferent between markets, the gas incumbent is less keen on a subset of regions, those markets will see a drop in competitive pressure because all but the local incumbent will "withdraw" from these submarkets, and prices will increase. The other markets, which the national incumbent views as relatively strong, will see a mixed effect: on the one hand all entrants will withdraw, but the global incumbent will retrench. The net effect of this is uncertain.

The discussion in section two provides more support for the former rather than the latter scenario. Ultimately, an assessment of the policy may require an empirical assessment of which firms impose the more important discipline on prices. We find no consistent evidence that the national incumbent had different mark-ups in different regional markets combined with different levels of sales; indeed both the quantitative evidence on sales and markups, and the qualitative marketing statements suggests a national approach by British Gas.

However in the case of non-discrimination rules introduced at the same time with respect to payment method, ${ }^{22}$ the effect was likely to be exactly as Ofgem intended. Both incumbents and entrants are likely to view direct debit payers, at whom most of the competitive activity is aimed, as constituting a 'strong' market relative to prepayers, so there is best reply symmetry in the sense of the literature review above. Non-discrimination clauses in this market would therefore raise direct debit prices and lower those for prepayment consumers, delivering broadly positive distributional effects, since prepayers have lower average income than the former. The gains for the low income group will be higher, the stronger is the competition for the 'strong', direct debit consumers. The more vigorously the companies compete for this market, the more the lower income consumers will

\footnotetext{
${ }^{22}$ Consumers generally pay either monthly in advance (direct debit); quarterly in arrears (standard credit); or by charging a card in advance which is inserted into a meter to release the energy supply (prepayment). Billing can be either paper based or accounts can be managed on-line.
} 
benefit from having their price 'tied' to those of the direct debit section of the market. The net effect on competition is likely to be positive and provide downward pressure on prices.

The interaction between the two non-discrimination clauses is less obvious. Recalling that the expected benefits from the ban on discrimination between payment methods arise from increased competition for the direct debit consumers, the lessening of competition brought about by the ban on discrimination between regions will very likely reduce these benefits. Theoretically one would then conjecture that the second ban (on regional price discrimination) may have an adverse effect on the benefits from the first ban.

\subsection{The effect of the clause on prices}

The regulator has been monitoring the effect of the non-discrimination clauses, and finds that prices have converged as intended (Ofgem, 2010a, reported in Appendix A), with average annual bill differentials across regions almost halving from $£ 30$ to $£ 18$ for standard credit consumers. Ofgem claims "This change has resulted from electricity suppliers reducing their in-area tariffs towards their out-of-area offerings and therefore represents a benefit to a large proportion of "sticky" customers who remain with their ex-incumbent supplier." (p. 14); but because of the volatility of the wholesale electricity market it is difficult to know what the counterfactual would have been, and so identify the direct effect of the non-discrimination clauses on price levels. In a separate document (Ofgem, 2010b), the regulator reports that dual fuel gross margins (charges net of wholesale costs and VAT) increased from $£ 75$ to $£ 215$ between May 2008 (before the non-discrimination clauses were widely anticipated) and December 2010; and that net margins (i.e. net of retail operating costs) increased from $-£ 40$ to $£ 90$ over the same period. This increase represents around ten per cent of the average dual fuel bill and triggered the energy regulator to announce a new enquiry into the retail energy market in November 2010 (Ofgem, 2010c). However many commentators believe that profits rise when wholesale prices fall, as they did over this period; in its own estimations, Ofgem (2008 p. 182) found some evidence of such an effect, but with a very wide range of possible impacts, some of them very 
small. The non-discrimination clauses in payment method are likely to have stimulated competition and reduced prices. So it is not clear that the lower differentials necessarily represent better value for consumers served by incumbents, and though they are not conclusive, the increased margins suggest they may reflect price overall rises (relative to costs) rather than the price falls which the regulator claims.

There is evidence that the clauses have had a small adverse effect on market activity. A crude model of the market share of the incumbent over time shows its inverse relationship to the gap between the incumbent's price and the prices of 'entrant' electricity companies. ${ }^{23}$ The regulator's own more sophisticated econometric model, using private information available from the firms, indicated that "a $1 \%$ rise in price of firm $i$, relative to average market prices, is associated with around a $2.5 \%$ increase in churn" (Ofgem, 2008, p.152). Ofgem presents some evidence of (initially small) adverse effects on consumer activity in the market following the non-discrimination clause, with switching levels falling slightly (Ofgem, 2010a). These falls might have been caused by a number of factors, including the cessation of rapid price increases across the market, and it is too early to detect a significant change in market share, but the regulator's own model clearly shows the potential adverse effect on consumer activity of reducing price differentials. This possible outcome was identified in the regulator's Impact Assessment (Ofgem, 2009a).

\footnotetext{
${ }^{23}$ To explore the role of price differentials in determining market share we ran the following regression in which all the coefficients are highly significant:

$$
M S_{\text {IncE }}=\begin{gathered}
67.57 \\
(1.24)
\end{gathered}-\underset{(0.017)}{0.069} \cdot(\text { Price Gap })-\begin{gathered}
2.43 \\
(0.27)
\end{gathered} \cdot t+\underset{(0.015)}{0.043} \cdot t^{2}
$$

Standard errors in brackets, $R^{2}$ within $=0.7902 ; R^{2}$ between $=0.5068, R^{2}$ overall $=0.4684$. Number of obs $=224$, number of groups $=14$, obs per group $=16$. F test that all $u_{i}=0: F(13,207)=53.74$. $\operatorname{Prob}>F=0.0000$.

The dependent variable, $M S_{\text {IncE }}$, is defined as the \% market share held by ex incumbent electricity supplier in each region at six monthly intervals from 2000 to 2008 (source Quarterly Energy Prices, published by Department of Energy and Climate Change). The independent variables are defined as follows: $t$ - time since market opened; $t^{2}$; "Price gap" - difference between charges to dual fuel direct debit medium consumer made by incumbent and average of non-incumbents, excluding British Gas (authors' calculations from price sheets downloaded from Which? and energywatch).
} 


\section{The object of the Ofgem exercise}

The regulator was concerned that the regional price differentials resulted in higher bills for those who had not switched supplier, and that non switchers included a larger than average proportion of consumers in vulnerable groups. Ofgem has a long-standing statutory duty to take account of the interests of certain groups of consumers: those of pensionable age, long term sick or disabled or who live in rural areas; consumers on low incomes were added under the Utilities Act, 2000. In its energy supply probe the regulator stated that it "owes a particular duty" to vulnerable consumers, and identified as potentially vulnerable not only those for whom it has a statutory duty, but also those "with low levels of literacy and numeracy or without a good command of English...; without a bank account ...; without easy internet access ... ; living in poor housing that is hard to heat; and restricted by their landlord from switching supplier." (Ofgem 2008 p. 115). ${ }^{24}$ While the regulator acknowledged that not all consumers in these categories are vulnerable with respect to energy supply, it estimated that between a quarter and a third of the population may be vulnerable in some way.

The regulator's supply probe confirmed that those paying by standard credit, without internet access, in rented accommodation, in DE social class and aged over 65 (or under 34) were less likely than average to have switched supplier. These non switchers were paying more for their energy than those who had changed to an entrant because incumbents levied higher charges.

"The actions of the most active consumers in driving prices down is not currently providing sufficient price protection to those who do not themselves participate in switching supplier frequently. Suppliers' ability to charge different prices enables them to hold prices higher to the inactive than the more active consumer groups. The relative inactivity of vulnerable consumer groups is hence of particular concern in this regard." (Ofgem, 2008, p. 122).

\footnotetext{
${ }^{24}$ This list does not include the category of vulnerability used in the fuel poverty definition, where a vulnerable household is defined as one containing children, or those who are elderly, sick or disabled.
} 
Ofgem's response was to strengthen and increase assistance to enable vulnerable consumers to participate more effectively in the market, including measures to improve information which suppliers are required to provide to consumers, helping indebted consumers who are currently blocked from changing suppliers, and improving sales and marketing activities. But the regulator wished to extend the benefits realised by switchers to non switchers more quickly than the market seemed to be delivering, stimulated by the overwhelming majority of the 'consumer lobby'. ${ }^{25}$

The literature and discussion in the previous section demonstrates that, at best, the in-area consumers who have not switched would enjoy lower prices and that this would only be true in some, not all regions. In the remainder of this section we make the extreme 'best case for Ofgem' assumption that in all regions, as a result of the intervention those currently with one of the regional incumbents will face lower prices. By making this assumption, one would hope that the available evidence supports the objective of benefiting the groups of vulnerable consumers identified above. We can identify which consumers would benefit relative to others in the market, i.e the characteristics of those who have stayed with the incumbent. Ofgem classifies non switchers according to 'vulnerable' groups in its energy supply probe (Ofgem, 2008) and we are able to use primary data from a 2005 consumer survey to identify which consumers fall into one or more vulnerable category.

Table 1 shows the proportions of switching consumers in each of the four groups for which the regulator has statutory responsibility, plus those with low educational achievement and without access to broadband in the home. This confirms the regulator's concerns that although a majority of those in most groups has switched electricity supply away from the incumbent, fewer amongst the vulnerable groups have done so than among consumers as a whole. These differences are significantly different from the average figures (at $1 \%$ level of significance) for all groups except the over $65 \mathrm{~s}$ and disabled consumers.

\footnotetext{
${ }^{25}$ Of the sixteen responses to the initial consultation on the new license conditions which were received from voluntary groups, fifteen strongly supported the introduction of undue discrimination conditions, many urged even stronger action, and only one raised any concerns about the potential effect on competition. Many respondents, including the Scottish government, seemed to believe that the non discrimination clause could protect some consumers while competition developed more fully.
} 
Given the narrowing of price differentials, the non switchers will have lost less from the non-discrimination clauses than those who have switched. Even so, almost a quarter of households with at least one 'vulnerable' characteristic will have lost immediately from the reform, since they are with an electricity entrant who has raised prices (out-of-area) to reduce their differentials. But in relative terms, the regulator's policies may have helped vulnerable consumers. The policy would be judged a success if relative fairness is more important than higher prices across the board.

Table 1: \% of consumer groups with different suppliers for electricity

\begin{tabular}{|c|c|c|c|c|}
\hline \multirow[t]{2}{*}{ Vulnerable group } & \multirow{2}{*}{$\begin{array}{l}\text { proportion of } \\
\text { respondents } \\
\text { in vulnerable } \\
\text { group }\end{array}$} & \multicolumn{3}{|c|}{$\%$ of vulnerable group supplied by: } \\
\hline & & $\begin{array}{l}\text { Incumbent } \\
\text { electricity co }\end{array}$ & British Gas & Entrants \\
\hline All respondents & $100 \%$ & 42 & 32 & 26 \\
\hline Over 65 & $15 \%$ & 46 & 28 & 26 \\
\hline Low income & $40 \% *$ & 47 & 31 & 22 \\
\hline Disabled & $9 \%$ & 44 & 28 & 28 \\
\hline Rural & $16 \%$ & 60 & 20 & 20 \\
\hline Low educational attainment & $20 \%$ & 52 & 27 & 22 \\
\hline Without Broadband & $65 \%$ & 45 & 31 & 24 \\
\hline At least one of the above & $56 \%$ & 47 & 29 & 24 \\
\hline
\end{tabular}

* There was a high refusal rate for the income question; Low income households were classified as those stating gross earnings were less than $£ 15,499$ per year, compared with national average gross annual earnings of $£ 21,736$ in 2005 .

Source: Primary data from CCP consumer survey 2005

However firms' responses to the non-discrimination clauses may have generated further detrimental distributional effects which may counter even the relative improvement in 'fairness' described above. Following representation from the industry, the regulator allowed firms to offer differential prices which might not be justified by cost if these were specifically designed to provide an initial offer to new consumers on a temporary basis (Ofgem 2009b p.12). Figure 1, taken from Ofgem (2010a, p. 16), shows that since the introduction of the non-discrimination clause the average offline tariffs have increased, but the size of discounts offered against these for on-line tariffs by the main players has increased dramatically; the variation between the discounts offered by different firms has 
narrowed since the very high range of discounts (around a quarter of the bill) when the probe was first published, as they have become more familiar with the new market circumstances. Vulnerable groups generally have lower access to broadband, raising concern for those who may find it difficult either to access these offers or understand their temporary nature, and the regulator has expressed concern about the transparency of these offers in its latest report (Ofgem, 2010a). From a competition perspective it is encouraging that the firms continue to compete actively for some segments of the market, rather than passively accepting the benefits offered by the non-discrimination clauses. Ironically, the non-discrimination clauses and their exceptions have offered new opportunities to segment the market and focus rivalry on a specific group of consumers, raising further questions about the trade-off between 'fairness' (interpreted as equal prices and access to offers for all) and competition.

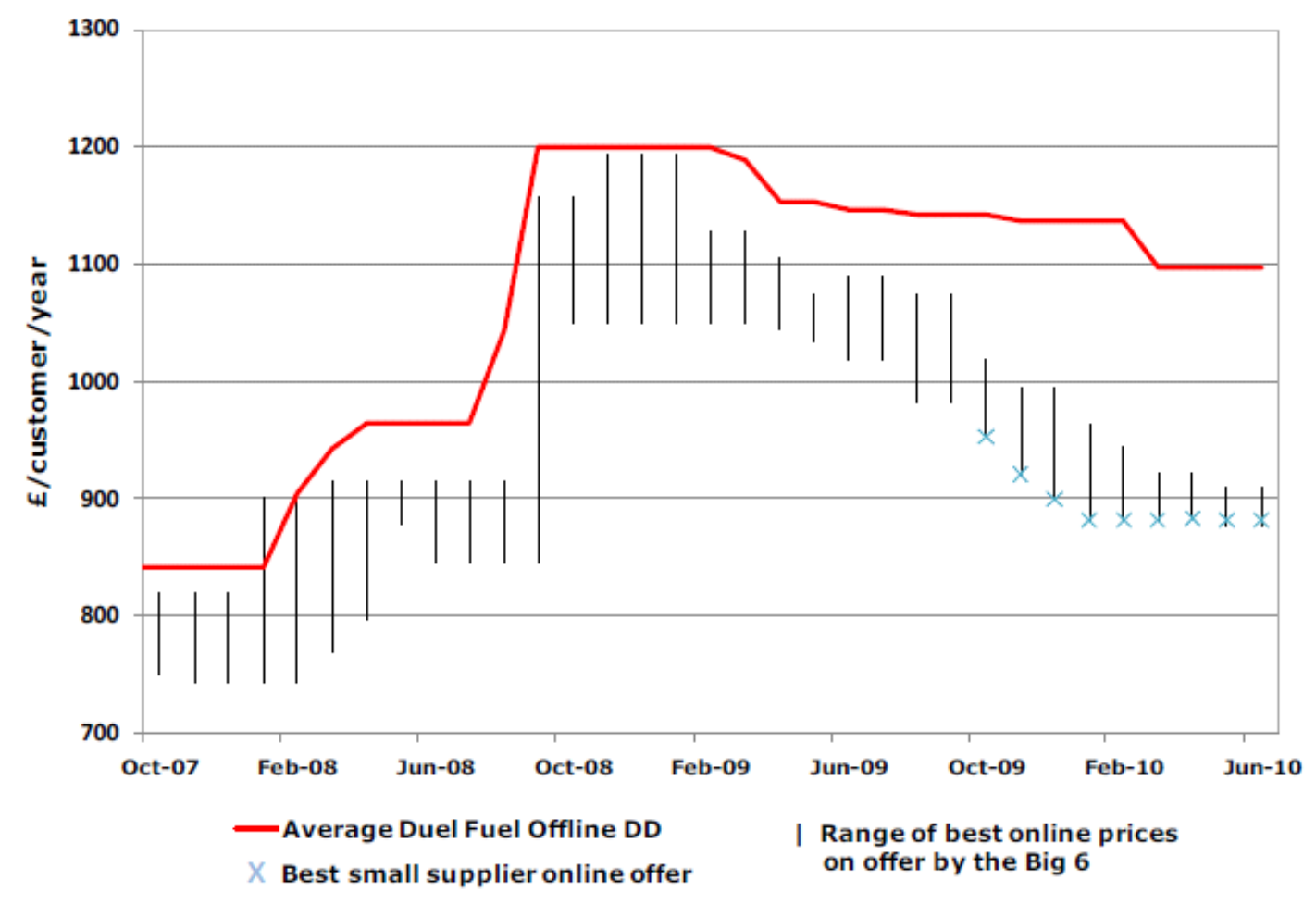

Figure 1: National average dual fuel offline bills vs. best offer online bills. (Ofgem, 2010a p. 16)

The trade off between fairness and competition in payment methods, where non- 
discrimination clauses were introduced at the same time, is rather different. Ofgem's cost analyses at the time of the probe (Ofgem, 2008) showed the highest margins for standard credit consumers who did not receive a prompt payment discount. Such consumers have historically experienced lower incomes and higher rates of fuel poverty than direct debit payers (Department of Energy and Climate Change, 2010a). Moreover competition is focused on those paying by direct debit and, as we see from figure 1, on online tariffs, so firms agree on the relative ranking of the consumer segments (best reply symmetry). Requiring non-discrimination in payment method should both strengthen competition and reduce the relative price charged to the high mark-up market, so that the policy is both distributionally progressive and pro competitive ${ }^{26}$. Unfortunately the simultaneous introduction of the geographical non-discrimination clauses will weaken these potentially positive effects.

\section{Concluding comments}

Ofgem justified its introduction of the non-discrimination clause by arguing for fairness, so that those whose vulnerability prevents them from switching suppliers are not (relatively) disadvantaged in the market. ${ }^{27}$ Models of price discrimination predict that the changes mandated by the European directive on non-discrimination in payment methods will help more low income consumers by lowering the price of standard credit supplies relative to direct debit. The potentially beneficial effects of this change depend on the maintenance of competition for the 'strong' market, in this case direct debit payers. Unfortunately it is this very rivalry which the non-discrimination clauses across regions are likely to have

\footnotetext{
${ }^{26}$ In fact Ofgem has found that the relative premium charged to this group of standard credit payers has risen since the probe (Ofgem 2010a)

${ }^{27} \mathrm{~A}$ similar argument was used by the parties in a 1984 US antitrust case, the Ethyl case, about the use of most-favoured-customer guarantees. Hay (1989) notes that one of the arguments put forward by the defendants in favour of the MFS was:
}

\footnotetext{
"The most-favored-customer clauses simply put into contractual language what the firms regarded as the sensible policy from a customer relations standpoint of not discriminating among customers by giving discounts that other customers would learn about anyway. Testimony indicated that customers on an individual basis desired contractual protection against discrimination." [p. 197]
} 
undermined. Because the companies differ in their views of strong and weak regional markets, the most likely net result of prohibiting geographical discrimination on prices is to raise them all, as predicted by the theoretical literature summarised in section three. The rising levels of both gross and net margins since the clauses were introduced provide some evidence that this has occurred. Although other factors, including the falling level of wholesale prices, will have contributed to greater profits, the regulator will want to take these adverse effects on competition into account in reviewing the non-discrimination clause. These follow from the weakening competitive threat from the entrants in each region. Confronted with this argument when it introduced the clauses, Ofgem recognised the dangers and made clear its preference for short term 'fairness' rather than longer term competition developments; it is ironic that the exceptions to the non-discrimination clauses (to enable competitive introductory offers) continue to raise exactly the same concerns and trade off. The policy was influenced by a common preference, exhibited by many campaigners, for national pricing so as to avoid 'post-code lotteries', even if the result is that everyone pays more. At a time when price levels of key basic commodities (energy, water, food) are expected to rise, and support for the most vulnerable in society may fall with cuts in government expenditure, such compromises are likely to be increasingly pertinent. Standard economic models, such as those presented here, provide recommendations which seem diametrically opposed to the preferences exhibited by many politicians and consumer groups. If policy makers are to be helped by economic models, this raises important and extensive challenges for an appropriate model to capture the preferences exhibited and choices implemented in practice. Such challenges are particularly timely as the regulator opens a new review of the retail energy market at the end of 2010 and reviews the non-discrimination clauses ahead of their 'sunset clause' in 2012. 


\section{Appendix: Further data on regional differences}

In Table A1 we show the number of gas and electricity consumers by region indicated by the name of the original electricity incumbent. We also show the ratio between these consumers, which is used to order the entries.

Table A1: Gas and Electricity consumers region

\begin{tabular}{|l|c|c|c|}
\hline region & $\begin{array}{l}\text { gas consumers } \\
\text { in thousands }\end{array}$ & $\begin{array}{l}\text { elec consumers } \\
\text { in thousands }\end{array}$ & ratio: $\frac{\text { gas }}{\text { elec }}$ \\
\hline Sweb & 973 & 1,489 & 0.65 \\
\hline Scottish Power & 1,285 & 1,968 & 0.65 \\
\hline Southern & 1,908 & 2,858 & 0.67 \\
\hline Northern & 1,037 & 1,551 & 0.67 \\
\hline Swalec & 722 & 1,070 & 0,67 \\
\hline Scottish Hydro & 478 & 709 & 0.67 \\
\hline Manweb & 1,015 & 1,465 & 0.69 \\
\hline East Midlands & 1,826 & 2.552 & 0.72 \\
\hline Eastern & 2,526 & 3,467 & 0.73 \\
\hline Seeboard & 1,731 & 2,230 & 0.78 \\
\hline London & 1,779 & 2241 & 0.79 \\
\hline Midland & 2,010 & 2,422 & 0.83 \\
\hline Norweb & 1,970 & 2,326 & 0.85 \\
\hline Yorkshire & 1,990 & 2,231 & 0.89 \\
\hline
\end{tabular}

Source: Column 2: Authors' calculations based on DECC, 2010b; column 3 Ofgem, 2007. 
Table A2 compares the prices of the two incumbents with the highest and lowest entrant price for May 2008. The data are ordered using the differences between the prices of the two incumbents.

Table A2: Prices for medium dual fuel with direct debit payment method May 2008

\begin{tabular}{|l|c|c|c|c|c|}
\hline Region & \multicolumn{2}{|c|}{ Incumbents } & \multicolumn{2}{|c|}{ Entrant } & Inc. > Ent \\
\hline Original incumbent & BG & Local & Highest & Lowest & \\
\hline Scottish Power & 1356 & 1356 & 1349 & 1273 & Yes \\
\hline Eastern & 1341 & 1342 & 1359 & 1300 & No \\
\hline Scottish Hydro & 1325 & 1322 & 1320 & 1274 & Yes \\
\hline East Midlands & 1335 & 1338 & 1354 & 1274 & No \\
\hline Southern & 1334 & 1329 & 1316 & 1295 & Yes \\
\hline Swalec & 1335 & 1326 & 1317 & 1300 & Yes \\
\hline Sweb & 1374 & 1364 & 1385 & 1342 & No \\
\hline London & 1377 & 1396 & 1362 & 1329 & Yes \\
\hline Manweb & 1330 & 1349 & 1353 & 1278 & No \\
\hline Yorks & 1363 & 1336 & 1349 & 1292 & Partly \\
\hline Seeboard & 1343 & 1379 & 1325 & 1271 & Yes \\
\hline Northern & 1304 & 1342 & 1308 & 1268 & Partly \\
\hline Midlands & 1368 & 1412 & 1346 & 1272 & Yes \\
\hline Source: Aus & 1338 & 1383 & 1323 & 1295 & Yes \\
\hline
\end{tabular}

Source: Authors' calculations taken from Consumer Focus (2008)

For the first seven entries, the difference is less than $1 \%$. 
Table A3 shows the regional difference in British Gas charges and distribution charges for May 2008. The prices are for a medium consumer paying by direct debit and are measured in £s.

Table A3: The regional difference in annual British Gas charges.

\begin{tabular}{|l|c|c|c|c|}
\hline Region & $\begin{array}{c}\text { Electricity } \\
\text { only }\end{array}$ & $\begin{array}{c}\text { Electricity distribution } \\
\text { charge }\end{array}$ & Difference & $\begin{array}{c}\text { Additional charge } \\
\text { for dual fuel }\end{array}$ \\
\hline East Midlands & 388 & 52.70 & 335.30 & 574.00 \\
\hline Eastern & 383 & 54.64 & 328.37 & 573.00 \\
\hline London & 384 & 53.11 & 330.89 & 573.00 \\
\hline Manweb & 405 & 62.42 & 342.58 & 574.00 \\
\hline Midlands & 390 & 52.48 & 337.52 & 574.00 \\
\hline Northern & 413 & 66.75 & 346.25 & 573.00 \\
\hline Norweb & 402 & 62.40 & 339.60 & 573.00 \\
\hline Scottish Hydro & 389 & 90.19 & 298.81 & 573.00 \\
\hline Scottish Power & 393 & 74.96 & 318.04 & 573.00 \\
\hline Seeboard & 370 & 47.97 & 322.03 & 573.00 \\
\hline Southern & 389 & 62.36 & 326.64 & 573.00 \\
\hline Swalec & 409 & 78.21 & 330.79 & 573.00 \\
\hline Sweb & 410 & 70.29 & 339.71 & 574.00 \\
\hline Yorkshire & 396 & 57.50 & 338.50 & 573.00 \\
\hline
\end{tabular}

Source: Charges from authors' calculations taken from Consumer Focus, 2008;

distribution costs from Energy Network Association, 2008 .

Other costs of electricity supply would include transmission costs (which will be lower in Scotland) which form a small part (around 3\%) of total costs, and are not publicly available. Including these would reduce the differences shown in the fourth column. The virtually identical additional charge to include gas as a dual fuel supply indicates that British Gas treats these as geographically uniform. The only publicly available costs are those of electricity distribution (Energy Networks Association, 2008). 


\section{BIBLIOGRAPHY}

Armstrong, M., 2008, "Price Discrimination", in P. Buccirossi (Ed.), Handbook of Antitrust Economics, MIT Press.

Bester, H. E. Petrakis, 1996, "Coupons and Oligopolistic Price Discrimination," International Journal of Industrial Organization, 14, 227-242.

Borenstein, S., 1985, "Price Discrimination in Free-Entry Markets", Rand Journal of Economics, 16, 380-397.

Bouckaert, J, Degryse, H. A. and T Van Dijk, 2008, "Price Discrimination Bans on Dominant Firms", TILEC Discussion Paper No. 2008-001.

Centrica, 2007, "British Gas announces second price cut of $£ 40$ - total reduction of $£ 207$ this year", press release, April 26th., http://www.centrica.co.uk/index.asp?pageid $=217 \&$ newsid $=1048$, accessed 2nd November 2010

Centrica, 2010, "British Gas cuts standard gas prices by an average 7\%", press release, February 4th., http://www.centrica.com/index.asp?pageid $=39 \&$ newsid=1941, accessed 2nd November 2010

Chen, Y., 1997, "Paying Customers to Switch", Journal of Economics and Management Strategy 6, 877-897.

Chen, Y. and Z.J. Zhang, 2009, "Dynamic Targeted Pricing with Strategic Consumers", International Journal of Industrial organization 17, 43-50.

Cooper, T.E., 1986, 'Most-favored-customer Pricing and Tacit Collusion', Rand Journal of Economics 17, 377-388.

Consumer Focus, 2008, Price comparison Fact Sheets, May 2008

Corts, K., 1998, "Third-Degree Price Discrimination in Oligopoly: All-Out Competition and Strategic Commitment", Rand Journal of Economics 29, 306-323.

Davies, S., Waddams, C. and C.M.Wilson, 2009, "How Far Does Economic Theory Explain Competitive Nonlinear Pricing in Practice?", CCP working paper 09-07

Department of Energy and Climate Change (DECC), 2010a, Annual Report on Fuel Poverty Statistics, October.

Department of Energy and Climate Change (DECC), 2010b, Sub-national gas sales and numbers of customers 2005, 2006,2007 and 2008, www.decc.gov.uk/en/content/cms /statistics/regional/gas/gas.aspx, accessed 29th November 2010. 
Dobson P.W. and M. Waterson, 2006, "Chain-Store Competition: Customized vs. Uniform Pricing", Warwick Economic Research Papers No 840

Energy Networks Association, 2008, DNO Tariff Tables, April, 2008

Esteves, R.B., 2009, 'Customer Poaching and Advertising', The Journal of Industrial Economics LVII, 1, 112-146

Fudenberg, D. J. Tirole, 2000, "Customer Poaching and Brand Switching," The RAND Journal of Economics 31, 634-657.

Giullietti, M., C. Waddams Price, M.Waterson, 2005, "Consumer Choice and Industrial Policy: a study of UK Energy Markets", The Economic Journal, 115, 949-968

Hay, G.A., 1989, "Practices That Facilitate Cooperation: The Ethyl Case ", in J. E. Kwoka and L. J. White (Eds), The Antitrust Revolution 1st edition, Oxford University Press.

Holmes, T., 1989, "The Effects of Third Degree Price Discrimination in Oligopoly", American Economic Review, 79, 244-250.

Hviid, M. and G. Shaffer, 2010, "Matching Own Prices, Rivals' Prices, or Both", Journal of Industrial Economics 58, 479-506.

Neilson, W.S. and H. Winter, 1993, "Bilateral Most-favored-customer Pricing and Collusion", Rand Journal of Economics 24, 147-155.

Neilson, W. and H. Winter, 1994, "Enhancing Bargaining Power with Most Favored Customer Pricing", Economics Letters, 44, 61-66.

Ofcom, 2010, Strategic Review of Consumer Switching.

Ofgem, 2007, Electricity Distribution Cost Review 2006-200\%.

Ofgem, 2008, Energy Supply Probe - Summary of Initial findings. http://www.ofgem.gov.uk/ Markets/RetMkts/ensuppro/Documents1/Probe\%20summary.pdf

Ofgem, 2009a, Addressing undue discrimination Final impact assessment, April

Ofgem, 2009b, Addressing undue discrimination Final proposals, April

Ofgem, 2010a, Update on Probe Monitoring: tariff differentials and consumer switching, July

Ofgem, 2010b, Electricity and Gas supply market Report December 2010, November 
Ofgem, 2010c, "Ofgem to review the effectiveness of the retail energy market", press release 26th November 2010.

Shaffer, G. and Z. J. Zhang, 1995, "Competitive Coupon Targeting, Marketing Science $14: 395-416$

Shaffer, G. and Z. J. Zhang, 2000, "Pay to Switch or Pay to Stay: Preference-Based Price Discrimination in Markets with Switching Costs", Journal of Economics \&6 Management Strategy 9, 397-424.

Shaffer, G. and Z. J. Zhang, 2002, "Competitive One to One Promotions", Management Science, 48: 1143-1160

Stole, L., 2007, "Price Discrimination and Competition", in M. Armstrong and R. Porter (Eds.), Handbook of Industrial Economics vol. III, North-Holland.

Thisse, J.F. X. Vives, 1988, "On the Strategic Choice of Spatial Price Policy," American Economic Review 78, 122-137.

Winter, R. A., 1997, "Colluding on Relative Prices", The RAND Journal of Economics 28, 359-371. 